\title{
To feel a look, to see the flesh: Phenomenological reflections of a pierced and tattooed pre-service teacher
}

\author{
Tanya Howard \\ University of Ottawa \\ howard.tanya@gmail.com \\ Rebecca Lloyd \\ rebecca.lloyd@uottawa.ca \\ University of Ottawa
}

If scholarship is an art-form, if teaching is an art-from, then scholar and teacher express themselves well... A body artist who is no good messes up the skin with ink blobs. Let us not teach in ink blobs, let us not write in ink blobs. (Morris, 2008, p. 100)

\begin{abstract}
This phenomenological reflection invites us to consider what it feels like to be looked at, as a visibly pierced and tattooed pre-service teacher, by a supervising principal. Drawing from Maurice Merleau-Ponty's phenomenology of perception, theories of the look in education forwarded by Madeleine Grumet, Michel Foucault's notion of the disciplinary gaze and Luce Irigaray's work on intersubjectivity, this article delves into the layers of meaning within a piercing moment. This inquiry thus fleshes out what it feels like to be seen as a body-modified teacher in comparison to that of the "expected teacher" image during a time of struggle when one's newly-forming teacher identity clashes with one's personal self-identity. It also provides context for better understanding, both palpably and politically, the sense of vision in education from various perspectives: looking within, looking down, the uniform look, the stereotypical look and the mutual look.
\end{abstract}

\section{Introduction}

Marla Morris' text invites us to consider the nature of expression, both of the self and through the medium of body art, in relation to the tumultuous process of becoming a teacher. For a pre-service teacher, the start of a career in education is a time filled with amorphous experiential "blobs" waiting to be refined into a more distinct vision of what it means to "become" a teacher. Interviews must be surmounted, supply teaching mastered, classroom management de-riddled, and report cards demystified. But before any of these challenges can be negotiated, novice teachers must first and foremost conquer what could very possibly the toughest personal challenge of all: assuming the look of a Teacher. For many educators, taking up an "expected" teacher identity, that is, one that parallels the conservative expectations of most elementary and secondary schools, causes significant distress (Britzman, 2006). What happens to those of us, especially newcomers to the field of education, who:

don't look like the teachers in the school where [we] are working? Or act like them? Or value what they value? How do you develop a teacher identity that is both accepted by the school 
and palatable to you? How do you get and keep a job without giving up the very essence of who you are?" (Britzman, 2006, p. xiv)

Internal struggles ensue. Push and pull forces surface with intensity, driven on one side by a career-oriented desire to impress the principal and secure a job, fuelled on the other side by a wish to hold onto who you are and what you believe in. These desires tug, wrench even, inexperienced teachers in uncomfortable opposing directions. This can leave beginning teachers with a disgruntled sense that they must play the part convincingly to fit in better with their established colleagues, often by downplaying or suppressing aspects of their self-identity or selfexpression in an effort to portray the expected teacher "look". Already vulnerable in their starting positions, frequently teetering on the edge of employment uncertainty and fierce job competition, it is not surprising that so many novice teachers, whether during the pre-service stage or when given their first classroom, choose conform to their school's status quo (Cole \& Knowles, 1993). Adopting the teacher images and behaviours that surround them becomes a coping mechanism to survive the pressures of breaking into a teaching career (1993). For many beginning educators, this pressure to conform first manifests during their teacher education programs. Practicum supervisors and university professors dole out warnings to students to be aware of the image they display during field placements, and even more importantly during job interviews (Colbert, 2008). With abundant reminders to cover the midriff, leave the flip-flops at home, and put forth a most impressive professional image possible (Atkinson, 2008), it is no wonder tensions between expressing self-image and repressing it in the name of getting hired are produced.

\section{To look within}

Wrapped up in my own anxious attempts to fit in as a pre-service teacher, I was no exception to feeling the acute pressure of these tensions during my Bachelor of Education days. My morning routine soon evolved to include an automatic self-check for teacher appropriateness: clothes professional, black nail polish removed, Doc Martins stowed in the closet, band t-shirts put away, and hair neatly done. But we all slip sometimes. Like a persistent stain that will be seen as it seeps through coats of concealing paint, markers for the non-teacher parts of our personalities have a way of leaking out in unplanned moments. These details are, after all, an integral part of who we are as individuals, multifaceted ones, at that. Sometimes, the pressure to fit into the professional setting simply cannot override the basal need to be who you are in a given moment. For me, it was the soft, simple joy of sunshine warming my face as I stepped outside for yard duty one morning that dissolved some of my careful guard and coaxed hidden parts of myself into view. It must have been my mood, infused as it was with lightness, that brought my hands to sweep through a carefree gesture of pulling my hair into a ponytail. Then, jarringly, it was as if a covered blot of ink had embarrassingly, unexpectedly, bled through my meticulously crafted presentable "teacher" surface to be caught by hyper-observant supervisory eyes. In one instant I was at home in my skin; in the next I felt painfully exposed.

I invite you now join me, to step into my flesh and feel the look with me as I reflect on this piercing moment. Feel my reactions as I recall what it was like to receive a look that penetrated far deeper than the surface of my skin, a look that bore into the sinews of my memory and caused me to seriously question what it means to live the pierced and tattooed teacher body: 
My stomach sinks in a sudden plummeting dive. I feel caught red-handed, as if cornered while performing a despicable act, a schoolyard transgression worthy of significant personal shame. The principal walks by silently, her eyes narrowed and her body posture suggesting firm disapproval. No words pass between us. Yet the message is clear: the conversation I was having with the grade five students about nine simple fragments of metal I wear in my ears was inappropriate.

As the shock of being "caught" slowly fades, I feel a hot flicker of anger and resentment flare up inside. This forces me to cast my eyes to the pavement and clench my teeth. I breathe in a hiss of air and try to shake myself out of the moment. A heavy awkward silence has seeped into what, until moments before, was an animated group discussion between some girls from my class and myself.

Despite my wardrobe and hair precautions, when I stepped outside for yard duty that particular morning, I forgot my self-imposed covering and absent-mindedly swept my hair up into a ponytail. About six girls flocked to me and excitedly asked me a flurry of questions: did they hurt, how old were you, did your parents let you have them? I happily answered: yes they hurt, I was sixteen for my first cartilage earring, and yes, my parents knew.

Then the principal's gaze halted me in my tracks. My mouth snapped shut.

I was prematurely robbed of a genuine moment of connection with the students.

The internal whisper of my professional conscience interrupts my brooding resentment. I do not want the students to see my anger. I regain my composure. I want to be professional. After all, I am just a student teacher, struggling to forge a firm footing during my practicum placement.

When I started my practicum placement, I made a conscious decision to wear my hair down to cover my body piercings. Most are located in the inner or upper cartilage of my ears. I also set aside a pile of long shirts to wear to school so that my navel piercing and tattooed lower back and torso would remain hidden.

Still, I find myself pondering a persistent question: Why is talking about my piercing offlimits? Are they so different from the pearls or gold hoops worn by other teachers on staff? If the principal reacted so strongly to this recess moment spurred on my multiple earrings, what would happen if my shirt slid up a little too far, and one of my tattoos was seen?

I am left with a lingering worry. How will I ever fit in here as a teacher?

(Personal journal, 2009).

I was not caught naked on the schoolyard that morning, but let me assure you I felt just as awkward, just as shamed, just as vulnerable, and just as put on display for the principal's judging eyes as if I had been cornered frisking behind the tetherball stand in my birthday suit. 
My body was clearly the catalyst for this moment of deeply felt malaise. More specifically my pierced body, standing adjacent to an exuberant bunch of students, is what captured the principal's eyes as they sharply raked over my visible body modifications ${ }^{\mathrm{i}}$, the metal rings, plugs and barbells housed in my ear cartilage. The look I received in that moment precipitated a wordless exchange that has since burned itself into the memories of my pre-service teaching days. The look passed over me in an instant, but mired me in self-doubt for months.

Madeleine Grumet (2007) reminds us that in the traditions of Western education and epistemology, disciplining and disappearing the body have become intrinsic practices, so intrinsic in fact, that when we readmit body consciousness to educational discourse, "in the very presence of toes or navels, gonads or drool, we [stand] mute and awed" (p. xv). While mute drooling awe is not quite what I strive for here, in the phenomenological exploration that follows, I do wish to draw careful attention back to the teaching body; the pierced and tattooed teaching body to be precise, adorned as it is with rings in the navel or drool on a lip ring, these markers of exterior difference which, in their eye-catching unusualness, seem to attract looks in school settings.

Grumet (1988) also refers to the look as a phenomenological event, in this case the look cast by a principal and received by a pre-service teacher (me); a look that interrupts a moment of student-teacher interaction. In "making the familiar" everyday occurrence of a supervisory gaze on the schoolyard "strange" (Sheets-Johnstone, 1998, p. 143), and in drawing to the forefront of attention the presence of my not-so-familiar piercings, I wish to usher you into the experience of "what it is like" (van Manen, 1997) to live with(in) the pierced and tattooed teacher's body and to feel the experience of being looked at.

As I focus on the rings, barbells, and ink inserted into my flesh and the tensions they produce, I also draw from Maurice Merleau-Ponty's (1968) phenomenology of perception and his assertion that the Flesh of our body is not just a container for our mind or biological matter, but is the prime element we use to experience the world, to come to know the world. The look is also an integral aspect of coming to know, experience, and even "touch" the world, as MerleauPonty further explains how the look "envelopes" and "palpates" visible things - teacher bodies included - and creates an intercorporeal interaction of bodies in relation to each other (p. 133). Within the intercorporeal relationship fostered by a look between a principal and a pre-service teacher, or a pre-service teacher and her students, lies the potentiality for meaningful intersubjective exchange. Luce Irigaray (2004) speaks of coming to know another person who is different from you, of the meeting of two different subjectivities. She explores the possibility of meeting in a way that acknowledges difference in the other in a non-objectifying, non-consuming manner, a meeting in which the other is not reduced to qualities like your own in an attempt to know the other better (2004). Thus, I organize this inquiry into what it is like for a bodymodified pre-service teacher to both repress and express herself around the phenomenon of seeing and being seen in supervisory and intersubjective capacities.

My hope is that by probing into the following phenomenological reflection, a steady confidence will begin to emerge that will help me - and possibly other pierced and tattooed preservice teachers like me - to endure harsh gazes cast in school surroundings regardless of how deep these looks penetrate one's consciousness. I also provide an experiential offering of what it feels like to be thick in the throes of forming and reforming blots of a coalesced identity for my evolving teacher "look," all the while being eyed by others and wondering to what extent they really see me. 


\section{To look down}

I will now proceed to peel back the layers of my experience on the schoolyard, with a mind to deepen an understanding of what occurred. I return to my journal reflection, which describes a scene wherein my conversation with students about my piercings was cut short by a principal's piercing gaze. And so it begins with a look cast towards me. The principal walks by silently, her eyes narrowed and her body posture suggesting firm disproval. Or, upon closer reflection, perhaps I should say it begins with a gaze rather than a look. For a gaze is objectifying, impersonal, whereas a look expresses subjectivity and specificity in a relationship (Grumet, 1988). In the fleeting instant when the principal's eyes captured mine, there was no spark of relation generated between us; we did not enter into mutual exchange or acknowledgement. It was a powerful gaze that descended upon me and effectively controlled my behaviour. Scrunched to angry slits and accompanied by firmly crossed arms, tight pulled lips, and a ramrod spine, her eyes trapped me like a fist closing around a butterfly and held me suspended in its paralyzing clasp. In that instant I became not a teacher speaking to grade five girls, but a loathsome specimen to be controlled for not acting as it "should." I shrank back from her gaze as my stomach plummeted to my feet. I felt the stinging disappointment of enthusiasm being quashed. Rings and barbells that had just seconds before felt light and right transmuted into a heavy guilty pull that dragged my head downward and brought the conversation to a halt.

"Supervise," from the Latin supervidere means to "look over," or "to inspect" (Online Etymology Dictionary, 2009), from a top-down trajectory. As I received a supervisory gaze, a wave of embarrassment, shame and guilt washed over me. Her eyes pinned me down. I felt like some bizarre exotic (and possibly toxic) insect that had been smashed between laboratory slides and shoved under the microscope for a closer, critical once-over. This supervisory gaze, when considered in this manner, constituted moment of discipline. By casting her piercing gaze my way, the principal efficiently and wordless curbed my behaviour and snuffed out the questionable conversation, bringing me back to the expected pre-service teacher comportment as quick as the blink of an eye. Or as fast as an unblinking glare.

Michel Foucault (1973) speaks of this disciplinary gaze, noting that it is both a way in which authorities watch over us and monitor our behaviour, as well as a way we look at our own behaviours. Whether an exterior gaze turned toward us by others, or the interior gaze we turn inwards on ourselves, this powerful gaze causes people to constantly monitor their bodies, actions, and feelings (Danaher, Schirato, \& Webb, 2001, p. 54). The principal not only monitored me that morning, or "looked over" me from her position of power as she inspected my actions; she also led me to regulate my own behaviour and feelings. One moment I felt content and comfortable, carefree and conversing with the students. Then her gaze punctured the moment. Trapped by authoritative eyes that have "caught me red-handed," I reacted by selfconsciously turning the look in on myself, reconsidering aspects of my body and my behaviour and searching for which elements of my "teacher self" have gone askew. Awkward and upset, I was jarred out of a rare joyous moment with the students. Hastily, I attempted to edit my behavior so the principal may observe something more to her liking: a novice teacher who does not dare to so boldly draw overt attention her body piercings in front of her grade five girls.

While this particular moment took me off guard and forced me to reckon directly with the effect of a rather bruising disciplinary gaze, in retrospect I realize I was aware of the potential power the gaze had to regulate my actions long before I set foot in the schoolyard. Recall that in the week before my practicum, I made a conscious decision to wear my hair down to cover my 
piercings... I also set aside a pile of long shirts to wear to school so that my navel piercing and tattooed lower back and torso would remain hidden. As my preemptive actions attest, I prepared myself for looks that might be critical and perhaps even powerful enough to have consequences on the success of my practicum. Michel Foucault would call my preparations "technologies of the self" (1973), which are "a series of techniques that allow individuals to work on themselves by regulating their bodies, their thoughts and their conduct" (Danaher, Schirato, \& Webb, 2001, p. 128). The insinuating words of my teacher education professors fed into the daily self-check I developed, with their repeated advice echoing in my head to be neat, clean, professional - in a word "conservative." Anxious to fit in at almost any cost, I opted to observe moderation in my own appearance. I chose to cover up, to hide parts of myself from the school community.

As I struggle through this process, I have come to understand what Stephanie Springgay \& Debra Freedman (2007) mean when they say "the body in education has become a site of disempowerment and enervation" (p. 3). Feeling powerless to work against authoritative principals and social norms in education, disempowered by cold gazes freezing me in their path, and unnerved to the point of choosing concealment over going against the grain, I turn to hiding aspects of my body and therefore sacrificing portions of my self-identity to fit into a teaching role. The truth remains: I would no sooner strip the tattoos from my skin or pull the piercings from my flesh than I would abandon my pursuit of classroom teaching. Yet, in my impressionable pre-service teaching stage, and even now as I begin to transition into my career in education, I feel that some level of compromise over my body modifications is a trade I am willing to make to allow my two divergent, competing selves coexist... For the moment.

\section{The uniform look}

Uniform comes from the Latin uniformis, meaning, "having one form" (Online Etymology Dictionary, 2009). Is there but "one form," or to be less extreme, a very narrow repertoire of forms for teachers to don as their "uniform" exterior look? Are the subjectivities available for the daily teacher image limited to "a small set of coercive identities," as MacLure suspects they are (cited in Hawkey, 1996)? Some days, especially when I have just tiredly tugged my shirt down over my tattooed hip for the hundredth time as I stretch to write at the top of the blackboard, I feel this might be so.

As a brand new teacher, I am stunned to discover that I have allowed myself to slip, with stinging resignation, into the restrictive straightjacket of the expected teacher look under the weight of others' eyes. I have succumbed to the Institution of Education, allowed it to take parts of my self-expression hostage, ransoming it off one ring, one tattoo at a time in exchange for another reprimand-free day standing at the front of the classroom and fulfilling yard duty duties. My flesh has become a complex story threaded through with themes of concealments and concerns, of hiding and deciding what to reveal and when. Anxiety and discomfort percolate through my pores, and my flesh no longer fits quite as I would like into all facets of my identity -a clash between the personal "me" and the teacher "me." And it all comes back to the look.

Gazes such as the one the principal pinned me with can have particularly potent affects on teachers' subjectivities, for as they stand in front of classrooms, receiving the gaze of students, teachers risk objectification and often cope with this by assuming "stereotyped costumes," (Grumet, 2003, p. 250). While I might not be willing to put on the full stereotypical teacher costume, I must acknowledge the more-than-likely possibility that I have cocooned myself in a 
costume of a different, subtler kind to hide me from gazing eyes. By concealing my tattoos with clothing and keeping a closed mouth about them, by wearing my hair down to cover my ears as a matter of course, I have created my uniform. Such a cloak allows me to slip into what I conceive is an "acceptable" teacher image for others to look at, without stripping myself completely bare of the details that privately form part of who I see myself to be.

\section{The stereotypical look}

When the principal used her gaze to press my self-expression back in on itself that morning in the schoolyard, I wonder: was she trying to preserve something of the uniform, conforming teacher image? Teachers' bodies, regardless of how unadorned and conventional or unusual and body-modified they might be, are firmly tied to institutional ideals of how they should look and act. As Neal Eastman (2006) further explains, the teacher's:

physical body is tied to institutional practice and convention to a second body - an institutional body - which participates in rituals of regimentation, regulation, domination, and discipline... [Many] possible interpretations of the teacher's body are continually foreclosed on ...[O]nly a narrow set of possible readings of the teacher's body are institutionally legitimate... (p. 300)

Was the principal using her gaze to foreclose the interpretation of a pierced teacher (one willing to discuss the nuances of needles, pain, and parental permission with young impressionable minds, no less) as a legitimate reading of a teacher body in her schoolyard? What then, if not like my inked and punctured form, does an "expected" teacher body look like?

Is the teacher a schoolmarm, perhaps, with a tight gray bun and a matching gray countenance? A crisp businesswoman sheathed in high heels and skirt suit, pressed to perfection and ready to perform in front of her pupils? Is "teacher" a kindly mother figure, swaddled in sweaters adorned with apples and crayons and school buses (Atkinson, 2008)? Does the teacher body blandly fade away amidst school walls, unassuming and rather unnoticeable in dull daily outfits (Atkinson, 2008; Johnson, 2006)? Is the teacher body ever so slightly subversively sexy in short skirts and vixen-worthy knee high boots (Johnson, 2006)? We all know that teachers can be soft and nurturing, with a gentle touch and a caring smile (Wall, 2008). Or they can be bumbling professor types, scatterbrained and rumpled but utterly amiable (Eastman, 2006). Some teachers are supremely professional with their ironed everything; others are infamous for donning kitschy themed accoutrements that coincide with seasonal holiday shifts - think springtime bunny earrings or midwinter snowman scarves (Atkinson, 2008). We've all known a teacher who wears a sweater vest, or thick glasses, or sports a tidy beard, or possibly even looks like an endearing "nerd" (Mitchell \& Weber, 1995). Set against these images, my piercings and tattoos feel at odds with these socially ingrained teacher image stereotypes. No wonder then, that as a brand new teacher seeking to eke out my place in the world of education, I so frequently find myself fretting over the ink injected into my pores and debating the career-path risk factor of new piercings. 


\section{To look back}

These common educator images, laden with apples, buns, high heels and the like irk me; they are ill-fitting skins and I personally disparage to don a single one of them. They feel like stock images, predictable paper dolls, cookie cutter appearances that vary with a few shades of difference but always end up easily or even instantly recognizable as Teacher. Over time, I have cultivated a distinct distaste for most everything so instantaneously identifiable as "teacher trademarks." This has, admittedly, developed into quite a repertoire of my own looks that I cast towards others when I am at school.

The eye-rolling look, for example, makes an appearance when I notice a teacher clad in a holiday vest with blinking lights. Unfair and assumptive, I cannot convince myself that the bearer of the light festooned garment would dare wear the same vest and walk around downtown or attend a public function. Other times I shoot slit-eyed glares toward "teacher babes" in their short shirts, tight shirts, and full makeup (Atkinson, 2008). Once again, I find myself drawing unfounded assumptions at their possible hidden agendas in wearing such sexual enticements to school. Resentful, baleful, scornful sneers have appeared, perhaps bred from my admittedly significant ignorance of makeup application. Then come the times when I can muster nothing more than a vacuous glance that glosses over such things as crew neck sweaters, plain button down shirts, and staffrooms full of featureless, androgynous khakis and pullover knits.

Some of my looks are significantly different, however, colored with admiration even. Slack jawed, I have caught myself outright staring in complete absorption, wide-eyed and envious, at teachers who exude auras of the unique, be it through purple hair and handmade clothing, an obsession with bizarre shoes, or the one male teacher on staff with a long ponytail paired with black jeans and a leather jacket.

Before I even realize what has happened, expressive looks of my own manifest in my eyes and on my face, becoming obvious indicators of my own disapproval, disinterest, or fascination with the teachers around me. When ensnared by the principal's gaze, I was just as surely glaring right back in anger, if not with my physical eyes than in my mind's eye, which vividly constructed for me the mental image of her navy skirt suit, gold jewelry, and silk blouse. I gazed at the principal with my own eyes in the week leading up to the schoolyard event, making observations of my own: her French manicured nails, her impeccable upswept hair, and her expensive Italian shoes. My gaze towards her became distant and disconnected, removed from what did not appeal to me personally after my own silent scrutinizing.

For all the impression the principal's gaze left on me, have I forgotten that my own gaze affects others? In truth, the constant suffocating pressure to make progress on my own career path pulls my attention away from how I gaze at others. But here, in the space of this paper where I continue to explore the phenomenon of seeing, being seen, and forming a teacher look, I find myself not only looking critically at those in positions of authority, but also peering back at myself. I have formed a preoccupation with how to produce a forced, awkward fit that brings my personal self and my teacher self into the same space like puzzle pieces mashed together to make them work cohesively, albeit uncomfortably.

\section{To look and see}

My modified body feels so much more noticeable now that "teacher" has been etched into the fabric of my identity alongside my dermal decorations. Yet even as it is noticed, I am not 
always comfortable with how it is seen. It used to be that being seen was a gratifying experience - showing off a tattoo at a convention or boasting a fresh piercing to friends. In my teaching experiences thus far, being seen has become less about being seen and more about receiving critical gazes and feeling uncomfortable in my own skin. Luce Irigaray (2004) reminds us what Maurice Merleau-Ponty says about the experience of being perceived in another's gaze, that, "in so far as I have a body, I may be reduced to the status of an object beneath the gaze of another person, and no longer count as a person for him" (p. 16).

But my body is so much more than an object, so much more than just an ambulatory flesh container to be lauded or critiqued like an object d'art in some living gallery for body modification. The objectifying gaze neglects to recognize the subjectivity that flows within my body. My body is my Being (Merleau-Ponty, 1968) in the world. How I perceive the world through my body and how others perceive my body becomes the fabric of my experiences.

Maurice Merleau-Ponty (1968) speaks of the chiasm, which he describes as the intertwining of the seer and the seen, of the flesh of Being with the flesh of the world. For Merleau-Ponty, "the flesh remains, in the broadest sense, an ontology of perception" (Leder, 1999, p. 203). To be in the world means to see and be seen. To perceive something, or someone makes it/them part of our experience, part of the flesh of the world, and thus part of our Being (Merleau-Ponty, 1968) in the world. "Another name Merleau-Ponty offers for the flesh is "visibility" (Leder, 1999, p. 203). There is no doubt that if the flesh of my body is visible, so too are my carefully selected piercings and tattoos. What I wonder about in these perceptual exchanges (such as when the principal perceives me) is just how much the Being of my Flesh is allowed to enter into the perceptual world of those who see me. Just how much does the chiasm allow my experiences to enfold into others' experiences? Does the objectifying gaze work to shut down the intertwining between of seer and seen (principal and teacher), between my world and theirs (body-modified, un-modified)?

\section{A curious, chiasmic look}

Marla Morris (2008) says, "[b]odyart should be a carnival of life. Bodyart educates for fullness of Being in the midst of a de-centered existence" (p. 100). Is this not what education is all about, to help others draw meaning from the world they exist in, from their very own Beings? The word educate comes from the Latin educare, which means to "bring out," "to lead," (Online Etymology Dictionary, 2009). I think back to that morning on the schoolyard, when the gesture of sweeping my hair back drew wide-eyed students to me like magnets. Recall how: About six girls flocked to me and excitedly asked me a flurry of questions: did they hurt, how old were you, did your parents let you have them? I happily answered: yes they hurt, I was sixteen for my first cartilage earring, and yes, my parents knew. I drew wonder from them. In my decade of living with my self-styled modified body, I have never had a child criticize a piercing or tattoo. They question, they touch, but they do not socially judge. Wonder is at the root of their openness towards my body. Their wonder "dislodges [them] from the prejudice of the everyday, publicly pregiven, traditional and worn out familiarity... drives from [them] the already authorized and expressly explicated interpretation of the sense of the world" (Fink, cited in Sheets-Johnstone, 1998, p. 327). The wonder brings them to question and to stare at my body. But their looks bear none of the critique the principal's gaze. A child will unabashedly ask questions with frank curiosity and disregard for taboos (which they have yet to learn exist). So, that thing lives right up your nose? It must get covered in boogies. They will poke and prod a tattoo to see how the 
skin behaves, peer with raw amazement through a stretched earlobe hole and ask if they can put a pencil in it.

They start to imagine how their bodies would feel with similar features. They tug at their ears, paste damp temporary tattoos to their arms and cheeks. Adults - most adults - do not explore the possibilities of body modification with such wonderment and abandon. Marla Morris (2008) further describes this distinction, "Children stare at tattoos. Adults are horrified... Children are more open to things than adults. Adults are so hardened in their belief systems that anything that threatens them is outlawed" (p. 91). Morris also finds that her students are more interested and accepting of her tigers than others. She tattooed her tigers to "scare away her illness," but she finds they scare other people away, too (p. 89). But not her students. "[M]y students think tattoos are cool. The ultimate in cool, in fact. Students often ask, 'Can we see your tattoos Dr. Morris?' I say, 'Only if you promise not to tell!' And so we share a secret, my students and I" (p. 89).

My piercings, unlike Marla Morris' tigers, were not kept secret. During that moment of spontaneous sharing while on yard duty, they were exposed for all to see. Had the principal looked at me with curious eyes rather than the glare, I would have just as enthusiastically expressed myself with her. Yet, she made me feel "caught me red-handed," monitoring, it would seem, for clandestine conversations about such shocking things as my ears. But, just as with Marla Morris's tigers and her students, my body piercings bridged sharing with my grade five girls. In their wonder, they were willing to meet the "me" inside the teacher figure, to become acquainted with my subjectivity in a way the principal did not.

As the students approached me in their wonder, the moment became more like an intertwining; the chiasm of Being Merleau-Ponty speaks of (1968). This chiasm is the conjunction, the exchange that is the fundamental intertwining of the seer and seen, of a "moment [that] resonates with a quite definite sense of recognition, of a felt truth sedimented in bodily being and manifest in our intercorporeal world" (Sheets-Johnstone, 1998, p. 31). Not a top-down gaze crushing me to silence, but a flowing exchange of seeing and being seen, a rippling intertwining between the students' and I as we slipped between question and answer, as I drew them out in their curiosity and ex-pressed parts of my subjectivity outwards to continue the conversation and build understanding.

\section{A mutual look}

Luce Irigaray $(2000 ; 2004)$ speaks of the encounter with the other, and reminds us how important it is not to reduce those who are different from us to something familiar. She emphasizes the importance of "finding gestures or words which will touch the other in his, or her, alterity" (2004, p. 29). The students in the schoolyard, in their innocent wonder, were happy to let me be different, to explore my ears in their unusual teacher alterity. As a result, they were able to share and understand part of my subjectivity and personal identity in a moment of productive intersubjective exchange. I pulled my hair back, my earrings were exposed, and the girls, upon seeing something outside their realm of personal experience, engaged me with a flurry of questions to explore this difference. The principal, by contrast, used her glaring eyes and "summoned [me] to come and join those who already make up the ranks of supposedly conforming human beings" (Irigaray, 2004, pp. 66-67).

In my flustered desire to fit in, I let go of my otherness; I let my hair down to cover up my difference under the weight of angry eyes. I slipped back into teacher conformity. The students 
knew better. They pinched their ears as they stared at mine, imagined my barbells in their own cartilage, tried my difference on for size, tasted its strangeness and looked to my subjectivity for answers their own did not supply.

\section{To look up}

If I have learned anything from this phenomenological reflection, it would be to take cues from my students. To let connections flourish between different individuals, to resist foreclosing the intersubjective exchanges offered by encounters with people who are not like us. Pierced and tattooed teachers work in plain sight in today's classrooms, but their experiences go virtually unnoticed to the point of invisibility. If I dare to teach about my modified body, if I nurture the awe and wonder it produces in students, think of what might be drawn forth.

Madeleine Grumet reminds us that curriculum "is our attempt to claim and realize selfdetermination by constructing worlds for our children that repudiate the constraints that we understand to have limited us" (cited in Pinar, Reynolds, Slattery, \& Taubman, 2000, p. 379). Perhaps I will find the courage to teach the "unthinkable" in my classroom and unabashedly speak aloud the stories that are hinted at by the images and accoutrements that adorn my skin. In working against my own fears of "being caught" by supervisory eyes, I can learn to allow body modifications to enter into valued classroom discussions. Perhaps then, students can learn to form confident understandings of their flesh in ways I have just begun to explore. Rather than operating under the constraints I currently feel as a novice teacher, the pressures I feel to hide and downplay my bodyart at school, I can instead help the body reappear as a site of legitimate consideration that is less about taboos and rules and expected images, and more about possibilities for shared opportunities to learn about self-expression and self-identity.

\section{Looking forward}

A glimmer of confidence has been sparked to life within me as I leave the early days of my teacher training behind and begin to negotiate my place in the world of education with less intimidation. I hope to let this newfound confidence grow over time into a full blazing warmth of comfort in my own flesh rather than a hot wave of anger, even when my body comes under scrutiny in the classroom or on the schoolyard. I can now look back on that moment between the principal and I not with a resentful scowl laced with embarrassment, but with a softer sense of quiet self-confidence. Next time, my eyes will not shoot downwards with anger. I will look right back with a steady openness that does not back down or walk away. No longer at the bottom of the gaze, crushed under the weight of judgmental glares, I will hold my eyes up, send my look directly back, and not feel shamed about aspects of my own body that I know are important to me.

Confronting icy glares with more confidence is just part of my hope for future moments of looking, seeing, and being seen. I hope too that my own eyes may soften as I look at other teachers, and allow them to be different in their flesh the way I am different in mine. Whether this means sending smiling eyes to teacher babes or gentler eyes towards the holiday vested colleague, I hope to create more of an intersubjective acknowledgment of difference between the teachers I meet and myself. For we are all different in our own right, and should learn to see each other as so, whether for lip rings and wrist tattoos, or for short skirts or apple knitted sweaters. 


\section{References}

Atkinson, B. (2008). Apple jumper, teacher babe, and bland uniformer teachers: Fashioning feminine teacher bodies. Educational Studies: Journal of the American Educational Studies Association, 44(2), 98-121.

Britzman, D. P. (2006) Foreword. In J. Alsup, Teacher identity discourses: negotiating personal and professional spaces (pp. ix-xvi). New Jersey: Lawrence Erlbaum Associates Inc.

Colbert, R. (2008). Teacher candidate fashion, tattoos, and piercings: Finding balance and common sense. Childhood Education, (Spring 2008), 158C-158E.

Cole, A. L., \& Knowles, J. G. (1993). Shattered images: Understanding expectations and realities of field experiences. Teaching and Teacher Education, 9(5-6), 457-471.

Conform. (n.d.). In Online Etymology Dictionary. Retrieved from http://www.etymonline.com/index.php?l=a.

Danaher, G., Schirato, T., \& Webb, J. (2001). Understanding Foucault. Delhi: Motilal Banarsidass Publishers Private Limited.

Eastman, N. (2006). Our institutions, our selves: Rethinking classroom performance and signification. Review of Education, Pedagogy \& Cultural Studies, 28(3), 297-308.

Educate. (n.d.). In Online Etymology Dictionary. Retrieved from

http://www.etymonline.com/index.php?l=a.

Featherstone, M. (Ed.). (2000). Body Modification. London: Sage Publications Ltd.

Foucault, M. (1973). The birth of the clinic: An archaeology of medical perception. New York: Pantheon Books.

Grumet, M. (2007). Foreword. In S. Springgay \& D. Freedman (Eds.) Curriculum and the cultural body (pp. xv-Xvi). New York: Peter Lang.

Grumet, M. (2003). Afterword: My teacher's body. In P. Freedman \& M. Stoddard Holmes (Eds.), The teacher's body: Embodiment, authority, and identity in the academy (pp. 245259). Albany: State University of New York Press.

Grumet, M. (1988). Bitter milk: Women and teaching. Amherst: The University of Massachusetts Press.

Hawkey, K. (1996). Image and the pressure to conform in learning to teach. Teaching and Teacher Education, 12, 99-108.

Howard, T. (2009). Unpublished personal journal.

Irigaray, L. (2004). Key Writings. New York: Continuum.

Irigaray, L. (2000). Why different? A culture of two subjects: Interviews with Luce Irigaray. L. Irigaray \& S. Lotringer, Eds. Translated C. Collins. New York: Semiotext(e).

Johnson, T. S. (2006). Performing A/Sexual teacher: The Cartesian duality in education. Review of Education, Pedagogy \& Cultural Studies, 28(3), 253-266.

Leder, D. (1999). Flesh and blood: A proposed supplement to Merleau-Ponty. In D. Welton (Ed.), The body (pp. 150-177). Oxford: Blackwell Publishers.

Merleau-Ponty, M. (1968). The visible and the invisible. Illinois: Northwestern University Press.

Morris, M. (2008). Teaching through the ill body: A spiritual and aesthetic approach to pedagogy and illness. New York: Sense Publishers.

Pinar, W.F., Reynolds, W.M., Slattery, P. \& Taubman, P.M. (2000). Understanding curriculum: An introduction to the study of historical and contemporary curriculum discourses. New York: Peter Lang.

Sheets-Johnstone, M. (1998). The primacy of movement. Philadelphia: John Benjamin North 
America.

Springgay, S., \& Freedman, D. (2007). Introduction: On touching and a bodied curriculum. In S. Springgay \& D. Freedman (Eds.) Curriculum and the cultural body (pp. xvii-xxvii) . New York: Peter Lang.

Supervise. (n.d.). In Online Etymology Dictionary. Retrieved from http://www.etymonline.com/index.php?l=a.

Uniform. (n.d.). In Online Etymology Dictionary. Retrieved from http://www.etymonline.com/index.php?l=a.

Van Manen, M. (1997). Researching lived experience: Human science for an action sensitive pedagogy. New York: University of New York State Press.

Wall, C. (2008). Picturing an occupational identity: Images of teachers in careers and trade union publications 1940-2000. History of Education, 37(2), 317-340.

Weber, S., \& Mitchell, C. (1995). That's funny, you don't look like a teacher! Interrogating images and identity in popular culture. London: The Falmer Press.

\footnotetext{
${ }^{\mathrm{i}}$ Mike Featherstone (2000) defines body modification as the process of making permanent or semi-permanent changes to one's body through procedures such as tattooing, body piercing, branding, and scarification
} 